\title{
ISOLASI DAN SELEKSI BAKTERI ENDOFIT UNTUK PENGENDALIAN PENYAKIT DARAH PADA TANAMAN PISANG
}

\author{
Husda Marwan', Meity S. Sinaga ${ }^{2}$, Giyanto² dan Abdjad Asih Nawangsih ${ }^{2}$ \\ ${ }^{1}$ Mahasiswa Program Doktor Sekolah Pascasarjana Institut Pertanian Bogor \\ e mail : husda04@yahoo.com \\ ${ }^{2}$ Departemen Proteksi Tanaman, Fakultas Pertanian, Institut Pertanian Bogor, Darmaga Bogor 16680
}

\begin{abstract}
Isolation and selection of endophytic bacteria to control blood disease on banana. Blood disease is one of the important diseases of banana in Indonesia. Endophytic bacteria have potencies as candidates of biocontrol agents to blood disease, because the bacteria colonized the same ecological niche with the plant pathogens. This research was conducted to isolate endophytic bacteria from banana root, and study their disease suppression ability to blood disease on banana. Ninety isolates of endophytic bacteria have been isolated from the root of banana. Average population densities of bacteria varied between $6,0 \times 10^{3}$ and $4,2 \times 10^{5} \mathrm{cfu} / \mathrm{g}$ fresh weight of root. Twenty seven isolates positively produced inhibition zone toward blood disease bacterium. Based on plant growth and disease suppression test, ten isolates promoted the growth of banana plant and four isolates suppressed the incidence of blood disease with ranged from 66,67 to $83,33 \%$.
\end{abstract}

Keywords : endophytic bacteria, blood disease, blood disease bacterium, banana

\section{ABSTRAK}

Isolasi dan seleksi bakteri endofit untuk pengendalian penyakit darah pada tanaman pisang. Penyakit darah merupakan salah satu penyakit penting pada tanaman pisang di Indonesia. Bakteri endofit berpotensi sebagai kandidat agensia pengendalian hayati penyakit darah, sebab bakteri endofit melakukan kolonisasi pada relung ekologi yang sama dengan patogen tanaman. Penelitian ini bertujuan untuk mengisolasi bakteri endofit dari akar tanaman pisang, dan menganalisis kemampuan bakteri tersebut dalam penekanan penyakit darah pada tanaman pisang. Sebanyak 90 isolat bakteri endofit berhasil diisolasi dari akar tanaman pisang. Rata-rata kerapatan populasi bakteri endofit bervariasi antara $6,0 \times 10^{3}-4,2 \times 10^{5} \mathrm{cfu} / \mathrm{g}$ berat basah akar. Sebanyak 27 isolat bakteri endofit mempunyai kemampuan antibiosis terhadap BDB secara in vitro. Berdasarkan hasil pengamatan terhadap pertumbuhan tanaman dan penekanan terhadap penyakit darah, sebanyak 10 isolat mampu meningkatkan pertumbuhan tanaman dan 4 isolat mampu menekan kejadian penyakit darah sebesar 66,67-83,33\%.

Kata kunci : bakteri endofit, penyakit darah, blood disease bacterium, pisang

\section{PENDAHULUAN}

Penyakit darah (blood disease) yang disebabkan oleh Blood Disease Bacterium (BDB) merupakan salah satu penyakit penting pada tanaman pisang di Indonesia (Supriadi, 2005). Infeksi BDB pada tanaman pisang dapat menyebabkan tanaman mati atau menghasilkan buah yang tidak dapat dikonsumsi. Daging buah pisang yang terinfeksi BDB menjadi berlendir yang mengandung massa bakteri.

Salah satu upaya untuk mengendalikan penyakit darah pada tanaman pisang adalah dengan aplikasi bakteri endofit. Menurut Kado (1992), bakteri endofit merupakan bakteri yang hidup di dalam jaringan tanaman tanpa merugikan bahkan memberikan banyak manfaat bagi tanaman inangnya. Bakteri endofit melakukan kolonisasi pada relung ekologi yang sama dengan patogen tanaman (khususnya patogen layu pembuluh), sehingga bakteri ini lebih cocok sebagai kandidat agensia pengendalian hayati (Hallmann et al., 1997).

Bakteri endofit menimbulkan banyak pengaruh menguntungkan terhadap tanaman inangnya, antara lain menstimulasi pertumbuhan tanaman (Sturz et al., 1997; Sessitsch et al., 2004; Adeline et al., 2008; Olmar et al., 2007; Chandrashekhara et al., 2007), memfiksasi nitrogen (Reinhold-Hurek \& Hurek, 1998; Bashan \& de-Bashan, 2005), dan menginduksi ketahanan tanaman terhadap patogen tanaman (Chen et al., 1995; Kavino et al., 2007; Chandrashekhara et al., 2007).

Berdasarkan hasil penelitian Hadiwiyono (2010), ditemukan perbedaan struktur komunitas bakteri endofit pada tanaman pisang terinfeksi BDB yang bergejala penyakit darah dengan pisang yang tidak bergejala. Dilaporkan ada bakteri endofit tertentu pada pisang yang tidak bergejala penyakit darah, tetapi bakteri endofit 
tersebut tidak dijumpai pada pisang yang bergejala penyakit darah. Bakteri endofit ini diduga terlibat dalam menghambat infeksi BDB pada tanaman pisang.

Penelitian ini bertujuan untuk mengeksplorasi isolat bakteri endofit dari tanaman pisang, menganalisis kemampuan antibiosis isolat bakteri endofit terhadap $\mathrm{BDB}$, menganalisis pengaruh bakteri endofit terhadap pertumbuhan tanaman pisang, dan menyeleksi bakteri endofit yang berpotensi untuk mengendalikan penyakit darah pada tanaman pisang.

\section{METODE PENELITIAN}

Tempat dan Waktu Penelitian. Penelitian ini dilakukan di laboratorium Bakteriologi Tumbuhan Departemen Proteksi Tanaman IPB dan Rumah Kaca Balai Besar Bioteknologi dan Sumberdaya Genetika (BB-BIOGEN) Bogor dari bulan Maret 2009 sampai September 2010.

Isolasi Bakteri Endofit dari Akar Tanaman Pisang. Bakteri endofit diisolasi dari akar beberapa jenis tanaman pisang yang tumbuh sehat dari sekitar pertanaman pisang yang terserang BDB dan akar tanaman pisang yang terserang BDB di daerah Bogor. Isolasi bakteri endofit dilakukan dengan metode pencawanan (plating). Akar pisang dicuci dengan air mengalir untuk membersihkannya dari partikel lain yang menempel, dikeringkan dengan kertas tissue, dan ditimbang masingmasing sebanyak 5 gram. Akar pisang disterilisasi permukaannya berdasarkan metode Sessitsch et al. (2004) yang dimodifikasi. Sterilisasi permukaan dilakukan secara berurutan dengan merendam akar pisang dalam Natrium hipoklorit $5 \%+0,25 \%$ Tween 20 selama 5 menit, dicuci sebanyak 4 kali dengan akuades steril dan dilewatkan (flaming) pada lampu bunsen.

Akar yang sudah disterilkan dipotong kecil-kecil menggunakan pisau skalpel steril dan dihaluskan dalam lumpang menggunakan mortar steril. Akar yang sudah dihaluskan dimasukkan dalam erlenmeyer yang berisi $45 \mathrm{ml}$ akuades steril, kemudian dilakukan pengenceran secara berseri sampai $10^{-3}$. Sebanyak $100 \mu 1$ dari pengenceran $10^{-1}$ dan $10^{-3}$ dibiakkan dalam media Tryptic Soy Agar (TSA) 50\% dan diinkubasi pada suhu ruang selama 24 - 96 jam.

Pengujian keefektifan dari sterilisasi permukaan dilakukan dengan membiakkan sebanyak $100 \mu \mathrm{l}$ akuades pencucian akar yang ke-4 pada media TSA dan diinkubasi pada suhu ruang selama 24 - 96 jam. Sampel akuades pencucian akar yang menunjukkan adanya pertumbuhan mikroorganisme tidak dapat digunakan sebagai sampel isolat bakteri endofit.

Pengamatan terhadap pertumbuhan bakteri endofit dilakukan pada 24, 48, dan 96 jam setelah inkubasi. Pengamatan dilakukan terhadap jumlah koloni bakteri yang tumbuh dan tipe morfologi koloni (Habazar \& Rivai, 2004). Koloni tunggal dari masing-masing sampel akar tanaman pisang yang menunjukkan perbedaan tipe morfologi dimurnikan kembali dalam media TSA $100 \%$ dan disimpan sebagai isolat. Masingmasing isolat dilakukan pengujian reaksi hipersensitif pada daun tembakau.

Uji Kemampuan Antibiosis Isolat Bakteri Endofit terhadap BDB. Pengujian dilakukan pada media Sukrosa Pepton Agar (SPA) dengan metode Difusi Kertas Cakram-Agar (Madigan et al., 1997). Masingmasing isolat bakteri endofit dibiakkan pada media TSA selama 48 jam, kemudian disuspensikan dalam $10 \mathrm{ml}$ akuades steril dan dihitung populasinya sehingga mencapai $10^{8}-10^{9} \mathrm{cfu} / \mathrm{ml}\left(\mathrm{OD}_{600}=0,16\right)$, sedangkan BDB dibiakkan pada media SPA selama 76 jam, kemudian disuspensikan dalam $10 \mathrm{ml}$ akuades steril dan dihitung populasinya sehingga mencapai $10^{8}-10^{9} \mathrm{cfu} /$ $\mathrm{ml}\left(\mathrm{OD}_{600}=0,1\right)$. Sebanyak $100 \mu \mathrm{l}$ suspensi BDB disebarkan pada permukaan media SPA secara merata dan dikeringanginkan. Selanjutnya, 5 potongan kertas saring steril dengan diameter $5 \mathrm{~mm}$ diletakkan secara teratur pada permukaan media. Sebanyak 5 potongan kertas saring ditetesi dengan 7,5 $\mu \mathrm{l}$ suspensi bakteri endofit yang berbeda dan 1 potongan kertas saring ditetesi dengan 7,5 $\mu 1$ akuades steril sebagai kontrol. Pengamatan dilakukan terhadap adanya zone bening di sekitar kertas saring yang merupakan reaksi penghambatan dari bakteri endofit terhadap BDB.

\section{Seleksi Bakteri Endofit Antagonis terhadap} Penyakit Darah. Seleksi dilakukan terhadap 30 isolat bakteri endofit yang memperlihatkan kemampuan antibiosis terhadap BDB dan isolat bakteri endofit yang dominan dalam satu komunitas berdasarkan frekuensi kemunculan isolat. Percobaan ini menggunakan Rancangan Acak Lengkap dengan tiga ulangan, tiap satuan perlakuan terdiri dari 4 bibit pisang. Inokulasi BDB pada tanaman yang telah diberi perlakuan dengan isolat bakteri endofit menggunakan dua metode (Rustam, 2007) yaitu: (1) Penginjeksian suspensi BDB pada bonggol tanaman pisang, (2) Pelukaan akar dan penyiraman suspensi BDB.

Bibit pisang yang digunakan adalah jenis pisang cavendish hasil perbanyakan dengan kultur jaringan dari 
BIOTROP Bogor yang telah diaklimatisasi selama 2 bulan. Bibit pisang diseleksi untuk mendapatkan bibit dengan ukuran tinggi dan jumlah daun tanaman yang seragam. Bibit dibersihkan perakarannya dari kotoran media pembibitan dengan air mengalir dan dikeringanginkan.

Bakteri endofit yang digunakan dalam pengujian ini diperbanyak pada media TSA dalam cawan petri dan diinkubasi selama 48 jam pada suhu ruang, kemudian ditambahkan $10 \mathrm{ml}$ akuades steril. Suspensi bakteri dihitung populasinya dan diencerkan sehingga populasinya mencapai $10^{8}-10^{9} \mathrm{cfu} / \mathrm{ml}$.

Bibit yang telah diseleksi direndam dalam $750 \mathrm{ml}$ suspensi bakteri endofit selama 6 jam (modifikasi Kavino et al., 2007), sedangkan tanaman kontrol direndam dalam akuades steril. Bibit yang telah diinokulasi dengan bakteri endofit ditanam dalam pot plastik (diameter 17 $\mathrm{cm}$ ) dengan media tanam berupa campuran tanah humus steril dan sekam bakar (perbandingan 2: $1 \mathrm{v} / \mathrm{v}$ ). Media tanam disiram dengan sisa suspensi bakteri endofit hasil perendaman. Bibit dipelihara selama 8 minggu untuk proses kolonisasi bakteri endofit pada bibit pisang. Selama proses kolonisasi bakteri endofit dilakukan pengamatan terhadap pertumbuhan tanaman (pertambahan tinggi dan jumlah daun tanaman) untuk mengetahui pengaruh perlakuan bakteri endofit terhadap pertumbuhan tanaman pisang.

Inokulasi BDB dilakukan pada bibit pisang 8 minggu setelah introduksi bakteri endofit (Kasutjianingati, 2004). Metode inokulasi BDB pada bonggol pisang dilakukan dengan cara menginjeksikan $2 \mathrm{ml}$ suspensi BDB $10^{8}-10^{9} \mathrm{cfu} / \mathrm{ml}$ menggunakan jarum injeksi steril $(5 \mathrm{ml})$ ke bonggol tanaman pisang. Metode penyiraman suspensi BDB pada akar dilakukan dengan cara melukai akar tanaman pisang dengan pisau skalpel steril, kemudian $25 \mathrm{ml}$ suspensi BDB $10^{8}-10^{9} \mathrm{cfu} / \mathrm{ml}$ disiramkan ke tanah sekitar akar yang dilukai. Pengamatan dilakukan terhadap periode inkubasi penyakit darah dan persentase kejadian penyakit darah. Persentase kejadian penyakit dihitung menggunakan rumus $\mathrm{KjP}=(\mathrm{a} / \mathrm{b}) \times 100 \%$, dengan $\mathrm{KjP}$ adalah kejadian penyakit layu (\%), a adalah jumlah tanaman yang menunjukkan gejala penyakit darah pada satu perlakuan, dan $b$ adalah jumlah tanaman yang diinokulasi dengan BDB pada perlakuan yang sama.

Data hasil pengamatan dianalisis secara statistik dan perlakuan yang berpengaruh nyata dilakukan uji lanjut Dunnett pada taraf 5\%.

\section{HASIL DAN PEMBAHASAN}

Isolasi Bakteri Endofit dari Akar Tanaman Pisang. Hasil isolasi bakteri endofit dari akar tanaman pisang diperoleh 90 isolat bakteri endofit yang terdiri dari 33 isolat dari pisang kepok, 31 isolat dari pisang raja, dan 26 isolat dari pisang ambon. Kerapatan populasi bakteri masing-masing tanaman sampel berkisar antara $6,0 \mathrm{x}$ $10^{3}$ sampai $4,2 \times 10^{5} \mathrm{cfu} / \mathrm{g}$ berat basah akar (Tabel 1).

Menurut Hallmann (2001) dan Zinniel et al. (2002), kerapatan populasi bakteri endofit tergantung pada jenis tanaman, umur tanaman, tipe jaringan (akar, batang, dan daun), habitat, dan faktor lingkungan. Pengaruh jenis tanaman pisang terhadap kerapatan populasi bakteri endofit dapat dilihat pada sampel tanaman pisang raja bulu dan ambon lumut yang berasal dari kebun PKBT IPB (Tabel 1). Kerapatan rata-rata populasi bakteri endofit dari sampel tanaman pisang raja bulu (RB1, RB2, dan RB3) lebih tinggi dibandingkan dengan ambon lumut (AL1, AL3, AL4, dan AL5).

Berdasarkan jenis tanaman pisang, kerapatan populasi bakteri endofit pada pisang raja $\left(1,09 \times 10^{5} \mathrm{cfu} /\right.$ $\mathrm{g}$ berat basah akar) lebih tinggi dari pisang kepok kuning $\left(5,15 \times 10^{4} \mathrm{cfu} / \mathrm{g}\right.$ berat basah akar) dan pisang ambon (4,09 × $10^{4} \mathrm{cfu} / \mathrm{g}$ berat basah akar). Hal ini sama dengan Harni (2010) yang melaporkan bahwa kerapatan populasi bakteri endofit pada tanaman nilam dipengaruhi varietas nilam. Selanjutnya Hung \& Annapurna (2004) menemukan variasi bakteri endofit pada spesies tanaman kedelai Glycine max dan G. soja.

\section{Uji Kemampuan Antibiosis Isolat Bakteri Endofit} terhadap BDB. Hasil pengujian antibiosis 90 isolat bakteri endofit terhadap BDB menunjukkan bahwa sebanyak 27 isolat (30\%) mempunyai kemampuan antibiosis terhadap BDB dengan diameter penghambatan yang bervariasi. Hal ini menunjukkan bahwa beberapa isolat bakteri endofit yang diisolasi dari tanaman pisang bersifat antagonis terhadap BDB. Hasil penelitian Long et al. (2004) menunjukkan bahwa 13 isolat bakteri endofit $(35 \%)$ dari tanaman Solanum sp. bersifat antibiosis terhadap Ralstonia solanacearum pada pengujian in vitro. Berdasarkan hasil pengujian in vitro aktivitas antibakteri, beberapa isolat bakteri endofit dari tanaman kentang bersifat antibiosis terhadap Streptomyces sp. dan Xanthomonas sp. (Sessitsch et al., 2004). Nawangsih (2007) juga melaporkan bahwa isolat bakteri endofit CA8 (genus Bacillus) dan PK5 (genus Pseudomonas) yang diisolasi dari sampel tanaman pisang mampu menekan perkembangan BDB secara in vitro. 
Tabel 1. Data hasil isolasi bakteri endofit dari akar beberapa jenis tanaman pisang

\begin{tabular}{llcc}
\hline \multicolumn{1}{c}{ Tanaman sampel } & Lokasi tanaman sampel & $\begin{array}{c}\text { Jumlah } \\
\text { koloni/gram akar }\end{array}$ & $\begin{array}{c}\text { Jumlah isolat } \\
\text { bakteri end ofit }\end{array}$ \\
\hline Kepok Kuning-1 & Pasir Kuda/Kebun PKB T IPB & $1,06 \times 10^{4}$ & 10 \\
Kepok Kuning-2 & Pasir Kuda/Kebun PKB T IPB & $8,60 \times 10^{3}$ & 6 \\
Kepok Kuning-3 & Pasir Muncang/Kebun Petani & $1,57 \times 10^{5}$ & 6 \\
Kepok Kuning-4 & Pasir Muncang/Kebun Petani & $6,06 \times 10^{4}$ & 6 \\
Kepok Tanjung & Pasir Kuda/Kebun PKB T IPB & $2,07 \times 10^{4}$ & 5 \\
Raja Bulu-1 & Pasir Kuda/Kebun PKB T IPB & $4,20 \times 10^{5}$ & 7 \\
Raja Bulu-2 & Pasir Kuda/Kebun PKB T IPB & $1,53 \times 10^{4}$ & 7 \\
Raja Bulu-3 & Pasir Kuda/Kebun PKB T IPB & $1,40 \times 10^{4}$ & 5 \\
Raja Nangka & Pasir Muncang/Kebun Petani & $7,60 \times 10^{4}$ & 5 \\
Raja Uli & Pasir Kuda/Kebun PKB T IPB & $1,73 \times 10^{4}$ & 7 \\
Ambon Lumut-1 & Pasir Kuda/Kebun PKB T IPB & $2,0 \times 10^{4}$ & 6 \\
Ambon Lumut-2 & Pasir Muncang/Kebun Petani & $2,66 \times 10^{4}$ & 6 \\
Ambon Lumut-3 & Pasir Kuda/Kebun PKB T IPB & $6,0 \times 10^{3}$ & 4 \\
Ambon Lumut-4 & Pasir Kuda/Kebun PKB T IPB & $6,5 \times 10^{4}$ & 4 \\
Ambon Lumut-5 & Pasir Kuda/Kebun PKB T IPB & $8,73 \times 10^{4}$ & 6 \\
\hline
\end{tabular}

Keterangan : PKB T IPB (Pusat Kajian Buah Tropika IPB Bogor).

Senyawa antibiotik yang dihasilkan oleh bakteri antagonis dapat berperan langsung sebagai bakterisida terhadap bakteri patogen dan agens penginduksi (elicitor) ketahanan tanaman terhadap penyakit (Lyon, 2007). Pada bakteri endofit, senyawa antibiotik yang dihasilkannya diduga lebih banyak berperan sebagai elicitor untuk menginduksi ketahanan tanaman dibandingkan berperan langsung sebagai bakterisida dimana bakteri endofit memerlukan kontak langsung dengan patogen tanaman. Hal ini disebabkan karena bakteri endofit yang berada dalam jaringan tanaman populasinya lebih sedikit dibandingkan dengan populasi patogen sehingga kemampuan dari bakteri endofit yang dapat melakukan kontak langsung dengan patogen lebih sedikit. Disamping itu, antibiotik yang dihasilkan oleh bakteri endofit dalam jumlah banyak pada jaringan tanaman dapat berpengaruh negatif terhadap pertumbuhan tanaman. Mourhofer et al. (1995) melaporkan bahwa antibiotik pyoluteorin dan 2,4diacetylphloroglucinol (DPAG) yang dihasilkan oleh Pseudomonas spp. bersifat fitotoksik pada konsentrasi tinggi.

\section{Pengaruh Bakteri Endofit terhadap Pertumbuhan}

Tanaman Pisang. Hasil penelitian menunjukkan bahwa inokulasi bakteri endofit berpengaruh nyata terhadap pertambahan tinggi dan jumlah daun tanaman pisang cavendish (Tabel 2). Berdasarkan hasil analisis terhadap pertambahan tinggi dan jumlah daun tanaman pisang, diketahui bahwa sebanyak 11 isolat bakteri endofit
(36,7\%) mampu meningkatkan pertambahan tinggi tanaman dan 12 isolat (40\%) mampu meningkatkan pertambahan jumlah daun.

Sessitsch et al. (2004) melaporkan bahwa $40 \%$ bakteri endofit yang diisolasi dari tanaman kentang mampu memacu pertumbuhan plantlet tanaman kentang. Hasil penelitian Adeline et al. (2007) menunjukkan bahwa bakteri endofit Serratia sp. yang diisolasi dari pisang liar mampu meningkatkan pertumbuhan plantlet pisang barangan kultivar Intan. Harni (2010) juga melaporkan bahwa 26 isolat bakteri endofit yang diisolasi dari tanaman nilam mampu meningkatkan pertumbuhan tanaman nilam (berat tajuk tanaman dan berat akar). Hasil penelitian juga menunjukkan bahwa 20 isolat bakteri endofit $(66,7 \%)$ yang diinokulasikan pada tanaman pisang cavendish tidak memberikan pengaruh terhadap pertumbuhan tanaman pisang (bersifat netral). Menurut Bacon \& Hinton (2007), interaksi antara tanaman inang dan bakteri endofit dapat bersifat netralisme (tidak ada pengaruh terhadap tanaman inang), mutualisme (menguntungkan terhadap tanaman inang dan bakteri endofit), atau komensalisme (menguntungkan terhadap tanaman inang atau bakteri endofit).

Berdasarkan variabel pertambahan tinggi dan jumlah daun tanaman pisang, sebanyak 10 isolat bakteri endofit (EAL09, EAL11, EAL15, EAL20, EKK11, EKK15, EKK22, ERB05, ERB06, dan ERB16 berpotensi sebagai agensia pemacu pertumbuhan tanaman pisang, karena isolat-isolat tersebut secara 
konsisten mampu meningkatkan pertambahan tinggi dan jumlah daun tanaman pisang cavendish. Hal ini diduga karena bakteri endofit dapat meningkatkan ketersediaan unsur hara tertentu dan menghasilkan hormon pertumbuhan tanaman seperti auksin dan sitokinin. Menurut Bacon \& Hinton (2007), bakteri endofit dapat meningkatkan pertumbuhan tanaman dengan cara meningkatkan ketersediaan nutrisi tanaman seperti nitrogen, fosfat, dan mineral lainnya, serta merangsang pertumbuhan tanaman dengan menghasilkan hormon pertumbuhan seperti etilen, auksin, dan sitokinin.

Pengaruh Bakteri Endofit terhadap Penyakit Darah pada Tanaman Pisang. Hasil penelitian menunjukkan bahwa perlakuan bakteri endofit berpengaruh nyata terhadap periode inkubasi dan kejadian penyakit darah pada tanaman pisang dari kedua metode inokulasi (Tabel 3). Pada metode inokulasi BDB dengan penginjeksian

Tabel 2. Pengaruh bakteri endofit terhadap pertambahan tinggi dan jumlah daun tanaman pisang cavendish pada 8 minggu setelah introduksi bakteri endo fit

\begin{tabular}{|c|c|c|c|}
\hline $\begin{array}{l}\text { Isolat bakteri } \\
\text { end ofit }^{\mathrm{a}}\end{array}$ & $\begin{array}{l}\text { Pertambahan tinggi } \\
\text { tanaman }(\mathrm{cm})\end{array}$ & $\begin{array}{l}\text { Pertambahan jumlah } \\
\text { daun tanaman (helai) }\end{array}$ & $\begin{array}{l}\text { Efek bakteri endofit } \\
\text { terhadap pertumbuhan }\end{array}$ \\
\hline EAL02 & 10,58 & $3,67 *$ & - \\
\hline EAL09 & $12,53 *$ & $3,38 *$ & + \\
\hline EAL11 & $12,66^{*}$ & $3,07 *$ & + \\
\hline EAL14 & 10,52 & 2,07 & - \\
\hline EAL15 & $12,18^{*}$ & $3,08 *$ & + \\
\hline EAL20 & $12,13 *$ & $3,25^{*}$ & + \\
\hline EAL26 & 10,64 & 2,05 & - \\
\hline E K K04 & 9,59 & 2,48 & - \\
\hline EKK07 & 8,94 & 2,40 & - \\
\hline E K K08 & 9,60 & 2,00 & - \\
\hline EKK10 & 10,37 & 2,62 & - \\
\hline EKK11 & $12,15^{*}$ & $3,67 *$ & + \\
\hline EKK 13 & 10,26 & 2,27 & - \\
\hline EKK15 & $11,72 *$ & $4,27 *$ & + \\
\hline E KK 20 & 9,63 & 2,13 & - \\
\hline EKK22 & $11,93^{*}$ & $3,23 *$ & + \\
\hline E K K26 & 9,93 & 2,28 & - \\
\hline Е КT02 & 11,27 & $4,43 *$ & - \\
\hline EKT0 3 & $11,73^{*}$ & 2,53 & - \\
\hline Е KT0 4 & 9,22 & 2,40 & - \\
\hline EKT0 5 & 8,85 & 2,57 & - \\
\hline ERB04 & 8,70 & 2,60 & - \\
\hline ERB05 & $12,99 *$ & $3,07 *$ & + \\
\hline ERB06 & $11,76^{*}$ & $3,07 *$ & + \\
\hline ERB08 & 10,07 & 2,53 & - \\
\hline ERB10 & 8,71 & 2,47 & - \\
\hline ERB16 & $12,07 *$ & $3,58 *$ & + \\
\hline ER N01 & 11,38 & 2,32 & - \\
\hline ER N05 & 8,40 & 2,07 & - \\
\hline ER U0 6 & 8,59 & 1,98 & - \\
\hline Kontrol & 9,41 & 1,53 & \\
\hline \multicolumn{4}{|c|}{$\begin{array}{l}\text { Isolat bakteri en dofit : EAL (Endofit Ambon Lumut), EKK (Endofit Kepok Kuning), EKT (Endofit } \\
\text { Kepok Tanjung), ERB (End ofit Raja Bulu), ERN (Endofit Raja Nangka), ER U (Endofit Raja Uli). } \\
\text { Efek pertumbuhan : + bakteri endofit dapat meningkatkan pertumbuhan berdasarkan variabel } \\
\text { pertambahan tinggg i dan jumlah daun tanaman, - perlakuan bakteri end ofit tidak berpengaruh } \\
\text { terhadap pertumbuhan tanaman diband ingkan tanaman kontrol. } \\
\text { * Rataan selajur berbeda nyata dengan kontrol berdasarkan uji Dunnett }(\mathrm{p}<0,05) \text {. }\end{array}$} \\
\hline
\end{tabular}


Tabel 3. Pengaruh bakteri endofit terhadap periode in kubasi penyakit, persentase kejadian penyakit, dan penekanan kejadian penyakit darah pada tanaman pisang Cavendish

\begin{tabular}{|c|c|c|c|c|c|c|}
\hline \multirow{2}{*}{$\begin{array}{c}\text { Isolat } \\
\text { Bakteri } \\
\text { Endofit }^{\mathrm{a}}\end{array}$} & \multicolumn{3}{|c|}{$\begin{array}{l}\text { Metode inokulasi: Penginjeksian suspensi } \\
\text { BDB pada bongg ol }\end{array}$} & \multicolumn{3}{|c|}{$\begin{array}{l}\text { Metode in okulasi : Pelukaan akar dan } \\
\text { penyiraman suspensi BDB }\end{array}$} \\
\hline & $\begin{array}{c}\text { Periode } \\
\text { in kubasi } \\
\quad(\mathrm{hsi})\end{array}$ & $\begin{array}{l}\text { Kejadian } \\
\text { penyakit } \\
(\%)\end{array}$ & $\begin{array}{c}\text { Pen ekanan } \\
\text { penyakit } \\
(\%)\end{array}$ & $\begin{array}{l}\text { Perio de } \\
\text { inkubasi } \\
\quad(\mathrm{hsi})\end{array}$ & $\begin{array}{l}\text { Kejadian } \\
\text { penyakit } \\
(\%)\end{array}$ & $\begin{array}{c}\text { Penekanan } \\
\text { penyakit } \\
(\%)\end{array}$ \\
\hline EAL02 & 6,83 & 100,00 & 0,00 & $11,97 *$ & 83,33 & 16,67 \\
\hline EAL09 & 6,33 & 100,00 & 0,00 & $14,17^{*}$ & 66,67 & 33,33 \\
\hline EAL11 & 8,00 & 100,00 & 0,00 & $14,00 *$ & 66,67 & 33,33 \\
\hline EAL 14 & 7,25 & 100,00 & 0,00 & $13,44^{*}$ & 66,67 & 33,33 \\
\hline EAL 15 & $10,50 *$ & $25,00 *$ & 75,00 & 11,00 & $16,67^{*}$ & 83,33 \\
\hline EAL20 & 7,00 & 100,00 & 0,00 & 11,11 & 83,33 & 16,67 \\
\hline EAL 26 & 6,83 & 100,00 & 0,00 & $11,78^{*}$ & 75,00 & 25,00 \\
\hline EK K04 & $8,67^{*}$ & 100,00 & 0,00 & $12,67^{*}$ & 75,00 & 25,00 \\
\hline EK K07 & $9,50 *$ & 100,00 & 0,00 & $13,10^{*}$ & 83,33 & 16,67 \\
\hline EK K08 & $8,83^{*}$ & 100,00 & 0,00 & $12,75^{*}$ & 100,00 & 0,00 \\
\hline EKK 10 & $10,00^{*}$ & 100,00 & 0,00 & $12,00^{*}$ & $33,33^{*}$ & 66,67 \\
\hline EKK11 & 6,94 & 91,67 & 8,33 & $11,86^{*}$ & 83,33 & 16,67 \\
\hline EK K13 & $8,83^{*}$ & 100,00 & 0,00 & $13,33^{*}$ & 66,67 & 33,33 \\
\hline EKK 15 & 7,17 & 100,00 & 0,00 & $14,00^{*}$ & 66,67 & 33,33 \\
\hline EK K 20 & 8,33 & $66,67 *$ & 33,33 & $12,40^{*}$ & $33,33^{*}$ & 66,67 \\
\hline EKK 22 & 6,67 & $50,00^{*}$ & 50,00 & $15,17^{*}$ & $25,00^{*}$ & 75,00 \\
\hline EK K 26 & $8,58 *$ & 100,00 & 0,00 & $13,28^{*}$ & 83,33 & 16,67 \\
\hline ЕКT02 & 6,00 & 100,00 & 0,00 & $12,22^{*}$ & 75,00 & 25,00 \\
\hline ЕКT03 & 7,58 & 100,00 & 0,00 & $12,22^{*}$ & 75,00 & 25,00 \\
\hline ЕК T04 & $8,42 *$ & $75,00^{*}$ & 25,00 & $12,44^{*}$ & $41,67^{*}$ & 58,33 \\
\hline ЕКT05 & $8,58 *$ & 100,00 & 0,00 & $13,81^{*}$ & 75,00 & 25,00 \\
\hline ERB0 4 & $8,67 *$ & 100,00 & 0,00 & $11,75^{*}$ & 100,00 & 0,00 \\
\hline ERB0 5 & 6,78 & 83,33 & 16,67 & $11,80^{*}$ & 66,67 & 33,33 \\
\hline ERB0 6 & $8,67 *$ & 100,00 & 0,00 & 10,89 & 75,00 & 25,00 \\
\hline ERB0 8 & 6,67 & 100,00 & 0,00 & $12,67^{*}$ & 75,00 & 25,00 \\
\hline ERB10 & $8,67 *$ & 100,00 & 0,00 & $13,33^{*}$ & 75,00 & 25,00 \\
\hline ERB 16 & $9,42 *$ & 100,00 & 0,00 & $13,50^{*}$ & 66,67 & 33,33 \\
\hline ERN01 & $10,33^{*}$ & 100,00 & 0,00 & $14,17^{*}$ & 100,00 & 0,00 \\
\hline ERN05 & $9,67 *$ & $75,00^{*}$ & 25,00 & $12,06^{*}$ & $58,33^{*}$ & 41,67 \\
\hline ERU06 & 8,33 & 100,00 & 0,00 & $12,50^{*}$ & 100,00 & 0,00 \\
\hline Kontrol & 6,33 & 100,00 & & 9,80 & 100,00 & \\
\hline
\end{tabular}

${ }^{a}$ Isolat bakteri endofit : EAL (End ofit Ambon Lumut), EKK (Endofit Kepok Kuning), EKT (End ofit Kepok Tanjung), ERB (End ofit Raja Bulu), ERN (Endofit Raja Nangka), ERU (End ofit Raja Uli)

* Rataan selajur berbeda nyata dengan kontrol berdasarkan uji Dunnett $(\mathrm{p}<0,05)$.

pada bonggol tanaman diketahui bahwa 15 isolat bakteri endofit mampu memperlambat munculnya gejala penyakit dan 7 isolat menekan kejadian penyakit dengan persentase penekanan $8,33-75,00 \%$, sedangkan pada metode inokulasi BDB dengan pelukaan akar dan penyiraman suspensi BDB diketahui bahwa 27 isolat bakteri endofit mampu memperlambat munculnya gejala penyakit dan 26 solat menekan kejadian penyakit dengan persentase penekanan $16,67-83,33 \%$.
Perbedaan pengaruh metode inokulasi BDB terhadap kemampuan antagonis bakteri endofit terjadi karena metode inokulasi BDB pada tanaman pisang mempengaruhi fase patogenesis yang dilalui patogen, sehingga berpengaruh terhadap kemampuan antagonis bakteri endofit dalam menekan munculnya gejala dan kejadian penyakit darah. Menurut Sinaga (2006), fase patogenesis dimulai dengan kontaknya inokulum pada permukaan jaringan inang (inokulasi), masuknya patogen 
ke dalam jaringan inang (penetrasi), infeksi patogen dalam jaringan inang, kolonisasi patogen dalam jaringanjaringan inang, dan penyebaran (diseminasi) inokulum ke jaringan/tanaman lain.

Metode inokulasi dengan penginjeksian suspensi BDB pada bonggol menyebabkan fase patogenesis BDB tidak berlangsung secara alami, karena patogen langsung melakukan infeksi dalam jaringan tanaman dan mengkolonisasi jaringan tersebut dengan populasi BDB yang diinjeksikan pada bonggol. Pada percobaan metode inokulasi ini, kemampuan bakteri endofit memperlambat munculnya gejala penyakit diduga disebabkan oleh adanya kemampuan antibiosis bakteri endofit terhadap BDB.

Metode inokulasi dengan pelukaan akar dan penyiraman suspensi BDB menyebabkan fase patogenesis BDB berlangsung secara alami, karena patogen melalui fase patogenesis secara bertahap dan kontiniu sampai munculnya gejala penyakit. Hal ini memungkinkan bakteri endofit yang telah berada dalam jaringan tanaman dapat melakukan berbagai kemampuan antagonisnya (antibiosis, kompetisi, dan induksi ketahanan sistemik) terhadap BDB, dimulai dari tahap awal fase patogenesis BDB. Aktivitas antagonis bakteri endofit pada percobaan metode inokulasi ini dapat dilihat dari perbedaan periode inkubasi penyakit dan persentase kejadian penyakit darah dengan metode inokulasi sebelumnya.

Berdasarkan kemampuan dalam menekan kejadian penyakit darah melalui metode inokulasi BDB yang telah dilakukan, diketahui bahwa isolat EAL15, EKK10, EKK20, EKK22 mempunyai potensi untuk dikembangkan sebagai agensia pengendalian hayati penyakit darah pada tanaman pisang dengan tingkat penekanan kejadian penyakit sebesar 66,67 - 83,33\%. Harish et al. (2008) melaporkan bahwa perlakukan kombinasi isolat bakteri endofit dan PGPR pada plantlet tanaman pisang mampu menekan kejadian penyakit Banana Bunchy Top Virus sebesar 20 - 80\%.

\section{SIMPULAN}

Bakteri endofit yang berhasil diisolasi dari akar tanaman pisang adalah 90 isolat, 33 isolat berasal dari pisang kepok, 31 isolat dari pisang raja, dan 26 isolat dari pisang ambon. Kerapatan populasi bakteri endofit berkisar antara $6,0 \times 10^{3}-4,2 \times 10^{5} \mathrm{cfu} / \mathrm{g}$ berat basah akar. Sebanyak 27 isolat tersebut mempunyai kemampuan antibiosis terhadap BDB secara in vitro.

Bakteri endofit mampu meningkatkan pertambahan tinggi dan jumlah daun bibit pisang cavendish. Hasil seleksi bakteri endofit terhadap penyakit darah diperoleh 4 isolat bakteri endofit potensial untuk mengendalikan penyakit darah pada tanaman pisang yaitu : EAL15, EKK10, EKK20, dan EKK22 dengan tingkat penekanan kejadian penyakit sebesar $66,67-83,33 \%$.

\section{SANWACANA}

Artikel ini merupakan bagian dari Disertasi pada Sekolah Pascasarjana Institut Pertanian Bogor. Terima kasih kepada DP2M DIKTI yang membantu pendanaan penelitian ini melalui program Hibah Bersaing DIKTI tahun 2009-2010 dan Dr. Ir. Supriadi, M.Sc (Balittro Bogor) atas informasi dan sarannya dalam pelaksanaan penelitian ini.

\section{DAFTAR PUSTAKA}

Adeline SYT, Sariah M, Jugah K, Son R \& Gurmit S. 2008. Endophytic microorganisms as potential growth promoters of banana. Biocontrol 53 : 541-553.

Bacon CW \& Hinton DM. 2007. Bacterial endophytes: The endophitic niche, its occupants, and its utility. In: Gnanamanickam SS. Gnanamanicham (ed.). Plant-Associated Bacteria. Springer, Berlin. p. 155-194.

Bashan Y \& de-Bashan LE. 2005. Bacteria, plant growth-promoting. In: Ensyclopedia of Soil in The Environment. (Editor-in-chief) D. Hiller, Elsevier Oxford UK. Pp. 103-115.

Candrashekhara, Sathyanarayana N, Saligrama AD, Kestur NA, Nandini PS \& Hunthrike SS. 2007. Endophytic bacteria from different plant origin enhance growth and induce downy mildew resistance in pearl millet. Asian Journal of Plant Pathology 1:1-11.

Chen C, Bauske EM, Musson G., Rodriguez-Kabana R \& Kloepper JW. 1995. Biological control of Fusarium wilt on cotton by use of endophytic bacteria. Biol. Control 5: 83-91.

Habazar T \& Rivai F. 2004. Bakteri Patogenik Tumbuhan. Andalas University Press. Padang.

Hadiwiyono. 2010. Penyakit darah pada tanaman pisang: Infeksi dan keanekaragaman genetika pathogen. [Disertasi]. Yogyakarta : Universitas Gadjah Mada. 
Hallmannn J, Quadt-Hallmann A, Mahaffee WF \& Kloepper JW. 1997. Bacterial endophytes in agricultural crops. Can. J. Microbiol. 43:895914.

Hallmannn J. 2001. Plant Interaction with Endophytic Bacteria. In: Jeger MJ, Spence NJ. editor. Biotic Interaction in Plant-Pathogen Associations. CAB International.

Harish S, Kavino M, Kumar N, Saravanakumar D, Soorianathasundaram K \& Samiyappan R. 2008. Biohardening with plant growth promoting rhizosphere and endophytic bacteria induce systemic resistance against banana bunchy top virus. Appl. Soil Ecology 39:187 200.

Harni R. 2010. Studi bakteri endofit untuk mengendalikan nematoda peluka akar (Pratylenchus brachyurus (Godfrey) Filipjev \& Stekhoven) pada tanaman nilam. [Disertasi]. Bogor: Program Pascasarjana, Institut Pertanian Bogor.

Hung PQ \& Annapurna K. 2004. Isolation and characterization of endophyte bacteria in soybean (Glycine sp.). Omnonrice 12: 92-101.

Kado CI. 1992. Plant Pathogenic Bacteria. p. 659674. In : Balows A, Truper HG, Dworkin M, Harder W, Schleifer KH. (ed.) The prokaryotes, vol. I. Springer-Verlag, New York.

Kasutjianingati. 2004. Pembiakan mikro berbagai genotip pisang (Musa spp.) dan potensi bakteri endofitik terhadap layu Fusarium (Fusarium oxysporum f.sp. cubense. [Tesis]. Bogor: Program Pascasarjana, Institut Pertanian Bogor.

Kavino M, Harish S, Kumara N, Saravanakumar D, Damodaranc T, Soorianathasundarama K \& Samiyappan S. 2007. Rhizosphere and endophytic bacteria for induction of systemic resistance of banana plantlets against bunchy top virus. Soil Biology \& Biochemistry 39: 1087-1098.

Long HH, Furuya N, Karose D, Yamamoto I, Takeshi M \& Takanami Y. 2004. Identification of the endophytic bacterial isolate and their in vitro and in vivo antagonist against Ralstonia solanacearum. J. Fac. Agr. Kyushu Univ. 49 (2):233-241.
Lyon G. 2007. Agents that can elicit induced resistance. In: Dale Walters, Adrian Newton, and Gary Lyon editor. Induced Resistance for Plant Defence: Sustainable Approach to Crop Protection. Blackwell Publishing.

Madigan TM, Martinko JM \& Parker J. 1997. Brock: Biology of Microorganisms. Eighth Edition. Prentice Hall International Inc. USA.

Mourhofer M, Keel C, Haas D \& Defago G. 1995. Influence of plant species on disease suppression by Pseudomonas fluorescens strain $\mathrm{CHAO}$ with enhanced antibiotic production. Plant Pathology 44: 40-50.

Nawangsih AA. 2007. Pemanfaatan bakteri endofit pada pisang untuk pengendalian penyakit darah: Isolasi, uji penghambatan in vitro dan in planta. J. Ilmu Pertanian Indonesia 12 (1):43-49.

Olmar BW, Celli RM, Ollin OV, Francisco COV \& Valeria MO. 2007. Interaction of endophytic diazotrophic bacteria and Fusarium oxysporum f.sp. cubense on plantlets of banana 'Maca'. Plant Soil 298:47-56.

Reinhold-Hurek B \& Hurek T. 1998. Interactions of gramineous plants with Azoarcus spp. and other diazotrophs: Identification, localization, and perspectives to study their function. Crit. Rev. Plant. Sci. 17:29-54.

Rustam. 2007. Uji metode inokulasi dan kerapatan populasi blood disease bacterium pada tanaman pisang. J. Hortikultura 17 (4):387392.

Sessitsch A, Reiter B \& Berg G. 2004. Endophytic bacterial communities of field-grown potato plants and their plant-growth-promoting and antagonistic abilities. Can. J. Microbiol 50:239249.

Sinaga MS. 2006. Dasar-dasar Ilmu Penyakit Tumbuhan. Cetakan ke-2. Penebar Swadaya. Jakarta.

Sturz AV, Christie BR \& Matheson BG. 1997. Associations of bacterial endophyte populations from red clover and potato crops with potential for beneficial allelopathy. Can. J. Microbiol 44: 162-167. 
Supriadi. 2005. Present Status of Blood Disease in Indonesia. In: Allen C, Prior P, Hayward AC editor. Bacterial wilt disease and the Ralstonia solanacearum complex. Minnesota: APS Press. Pp. 395-404.
Zinniel DK, Lambrecht P, Harris NB, Feng Z, Daniel K, Phyllis H, Carol AI, Alahari A, Raul GB \& Anne KV. 2002. Isolation and characterization of endophytic colonizing bacteria from agronomic crops and prairie plants. App. Env. Microbiol. 68: 2198-2208. 